\section{Spondylurus martinae (Saint Martin Skink). Distribution.}

Date of observation: 10 March 2013. Location: Saint-Martin (French Side), Île Tintamarre. Coordinates: 18.12, -62.982. Elevation: $13 \mathrm{~m}$. Voucher: image. This is the first sighting of this native species on île Tintamarre $\left(1.20 \mathrm{~km}^{2}\right)$, a currently uninhabited French islet located $2.9 \mathrm{~km}$ east of the main island of Saint Martin. The coastal strip of Tintamarre belongs to the Conservatoire du Littoral (coastal protection agency) and is a part of Saint-Martin's Nature Reserve. The inner area, including the largest part of the skink's habitat, belongs to a private owner. During 8-10 March, 2013, we made ten observations of skinks on dry stone walls, corresponding to at least eight different individuals. Based on photographs, we tentatively assigned this population to the Saint Martin Skink, Spondylurus martinae, described in 2012 based on old specimens collected twice: once in the 19th century and a second time around 1965 (Hedges, B. \& Conn, C.E., 2012, A new skink fauna from Caribbean islands [Squamata, Mabuyidae, Mabuyinae], Zootaxa, 3288, 1-244.) Hedges \& Conn assessed S. martinae to be critically endangered, and possibly extinct, mainly due to predation by the Small Indian Mongoose (Urva auropunctata), introduced on Saint Martin Island at the end of the 19th century. Mongooses are absent on Tintamarre, as is the case on Terre de Bas (Guadeloupe: îles de La Petite Terre) where there is a skink population tentatively assigned to Mabuya desiradae (Lorvelec, O., 2011, Mabuya mabouya [Lesser An- tillean Skink], conservation, Caribbean Herpetology, 2:19). On these two islets, dry-stone walls probably provide last refugia for skinks against the introduced Roof Rat (Rattus rattus).

Olivier Lorvelec, INRA, UMR0985 Ecologie et Sante des Ecosystemes, Campus de Beaulieu, Rennes, Bretagne, 35000, France, Olivier.Lorvelec@rennes.inra.fr; Benoit Pisanu, MNHN, UMR7204 Conservation des Especes, CNRS-P6, 61 rue Buffon, Paris, Ile-de-France, 75231, France, esnm2@mnhn. fr; Aurelien Schmitt, 4 rue Jean Le Moal, Vannes, Bretagne, 56000, France, aurelienschmitt.1@gmail.com; and Tommy Vallon, 22 residence Ezana, Saint-Francois, Guadeloupe, 97118, France, tommy971@hotmail.com.

Citation: Lorvelec O, Pisanu B, Schmitt A, Vallon T. 2013. Spondylurus martinae (Saint Martin Skink). Distribution. Caribbean Herpetology 39:1.

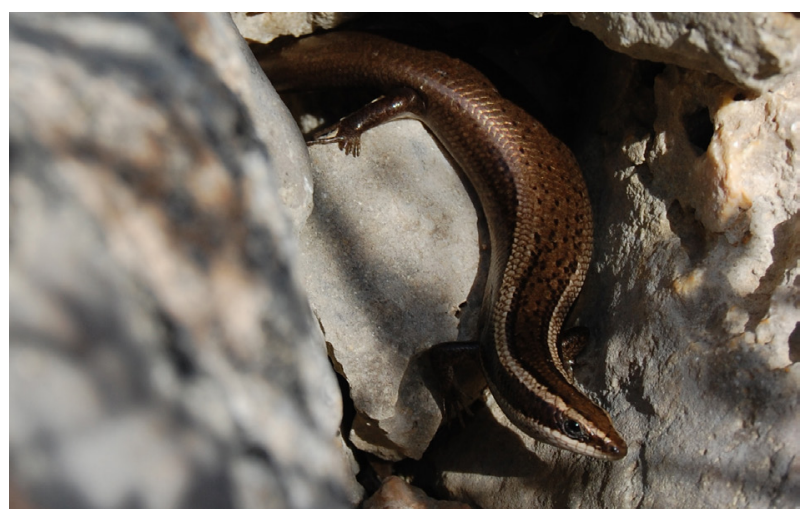

Photograph by B. Pisanu

Published online 23 April 2013 